\title{
Survey among employers of alumni from the Faculty of Economics and Business Administration of Universiteit Maastricht
}

Citation for published version (APA):

Allen, J. P., \& Ramaekers, G. W. M. (2006). Survey among employers of alumni from the Faculty of Economics and Business Administration of Universiteit Maastricht. Researchcentrum voor Onderwijs en Arbeidsmarkt, Faculteit der Economische Wetenschappen. ROA Reports No. 1E https://doi.org/10.26481/umarep.200601E

Document status and date:

Published: 01/01/2006

DOI:

10.26481/umarep.200601E

Document Version:

Publisher's PDF, also known as Version of record

Please check the document version of this publication:

- A submitted manuscript is the version of the article upon submission and before peer-review. There can be important differences between the submitted version and the official published version of record.

People interested in the research are advised to contact the author for the final version of the publication, or visit the DOI to the publisher's website.

- The final author version and the galley proof are versions of the publication after peer review.

- The final published version features the final layout of the paper including the volume, issue and page numbers.

Link to publication

\footnotetext{
General rights rights.

- You may freely distribute the URL identifying the publication in the public portal. please follow below link for the End User Agreement:

www.umlib.nl/taverne-license

Take down policy

If you believe that this document breaches copyright please contact us at:

repository@maastrichtuniversity.nl

providing details and we will investigate your claim.
}

Copyright and moral rights for the publications made accessible in the public portal are retained by the authors and/or other copyright owners and it is a condition of accessing publications that users recognise and abide by the legal requirements associated with these

- Users may download and print one copy of any publication from the public portal for the purpose of private study or research.

- You may not further distribute the material or use it for any profit-making activity or commercial gain

If the publication is distributed under the terms of Article $25 \mathrm{fa}$ of the Dutch Copyright Act, indicated by the "Taverne" license above, 
Survey among employers of alumni from the Faculty of Economics and Business Administration of Universiteit Maastricht

ROA-R-2006/1E

Jim Allen

Ger Ramaekers

Research Centre for Education and the Labour Market

Faculty of Economics and Business Administration

Maastricht University

Maastricht, January 2006 
ISBN-10: 90-5321-426-7

ISBN-13: 978-90-5321-426-8

Sec05.137.doc 


\section{Abstract}

In selecting new graduates, companies and institutions take not only the graduates' knowledge but also his or her interpersonal skills, analytical skills, long-term development potential, fit in organisational culture and management skills into account. They also put a lot of weight on these skills.

Elaborating on the insight gained by our annual graduate research, these finding may not come as a surprise, but now - being able to ask the employers - the findings are confirmed by this employer survey.

Entrepreneurial skills play less often than the above mentioned skills a major role in the selection process, but when they do they are given more than average weight. On all of these selection criteria, graduates from Universiteit Maastricht score at least average or more often above average in the eyes of employers. According to employers Universiteit Maastricht graduates in particular clearly score above average with respect to interpersonal skills and problem solving skills.

In this respect it should be mentioned that most employers (64\%) are familiar with the unique selling point of Universiteit Maastricht: it's PBL approach. The majority of them believe that differences between Universiteit Maastricht and other graduates are related to PBL. One employer characterised Maastricht graduates as follows: "much more sociable; better team players (real team players instead of 'people in a group'); consensus based; good problem solving skills".

Apart from the insights gained, the general merit of this employer survey is to establish/improve the faculty's contacts and relations with the employers of its graduates. 



\section{Contents}

Preface

1 Introduction 1

2 Characterisation of the companies 3

3 Recruitment- and HRD policy $\quad 7$

4 Selection criteria $\quad 11$

5 Rating of university graduates $\quad 19$

6 Demand for closer ties with the Faculty of Economics and Business Administration 23

$\begin{array}{lll}7 & \text { Findings } & 25\end{array}$

Appendix 1: Companies that participated in the employer survey 27

Appendix 2: Questionnaire employer survey $\quad 29$

Appendix 3: Classification of the other selection criteria 37 



\section{Preface}

Commissioned by the Board of Governors of Universiteit Maastricht (UM), the Research Centre for Education and the Labour Market (ROA) annually conducts a survey into the labour market entry and careers of UM graduates. The survey consists each year of three measurements: respectively approximately 1.5 years after graduation and since 1998 also 5.5 years and 10.5 years after graduation. What was lacking was a survey among the graduates' employers. Fortunately, early 2005 the Corporate World Project (CWP) of the Faculty of Economics and Business Administration (FE\&BA) of the UM commissioned the ROA to conduct a survey among employers of FE\&BA graduates.

ROA supervised the research project, and was responsible for the development of the questionnaire, the quality control and the report. The research project was carried out in cooperation with the survey bureau Flycatcher. The latter was responsible for the data-collection and -processing.

From the CWP working group the research project was looked after by Leann Poeth en Peter Otten, who both have been closely involved in developing the questionnaire and who personally approached the employers with the request to participate in the employer survey. Within ROA the questionnaire was developed by Jim Allen, Hans Heijke and Ger Ramaekers, the project manager. Lieke Helmes coordinated the activities of Flycatcher in the research project.

We thank the employers of the FE\&BA graduates for their willingness to participate in the employer survey.

Maastricht, January 2006 



\section{Introduction}

\section{Outline of the project}

Against the background of profiling and accreditation the Faculty Board of the FE\&BA wants to establish and/or improve the faculty's contacts and relations with the employers of its graduates. In this regard, the Faculty Board initiated the Corporate World Project (CWP). The CWP working group consists of: Ursula Glunk, Maurice Olivers, Peter Otten, Leann Poeth-Chervenic, Bart Remmen and Ingrid Wijk. The CWP working group has taken on to realise a number of projects in the academic years $2004 / 2005$ and $2005 / 2006$, including a survey among employers of graduates of the FE\&BA.

The employer survey was designed and carried out by Leann Poeth-Chervenic and Peter Otten from the CWP working group and by Jim Allen and Ger Ramaekers from the ROA. The CWP working group asked the ROA to participate in the employer survey because of the ROA's experience with graduate surveys and because ROA already gained experience with employer surveys in 2 pilot projects. In both pilot projects graduates were asked to pass the questionnaire on to their employer. This approach automatically creates a representative sample of graduates' employers. Moreover, this design makes it possible to link information from the graduates themselves with information from their employers. Unfortunately the response in both pilot projects proved to be very low. ${ }^{1}$ Based on these disappointing experiences it was decided for this employer survey to straightforwardly approach the employers, and not to use graduates to approach the employers.

\section{Research population and data collection}

The research population consists of 75 Dutch- and abroad-based companies and institutions ${ }^{2}$ that employ graduates of the FE\&BA. In total, these 75 companies employ approximately 650 of FE\&BA graduates. These companies were selected on the basis that they employ at least three (3) graduates of the FE\&BA. The data was obtained from the database of the general UM alumni office. In January 2005, in co-operation with the Maastrichts Economen Verband (alumni association of the FE\&BA), the database was updated and now includes the names of the employers of some 1,800 of the FE\&BA graduates (out of a total of some 5,300$)$.

The person contacted for the employer survey was the person responsible for recruiting university graduates. Since this information was not always known,

1. Ramaekers, G., Allen, J., Heijke, J., Loo, J. van, Velden, R. van der (2004), Methodiek Werkveldonderzoek Hogeschool INHOLLAND, Maastricht: Researchcentrum voor Onderwijs en Arbeidsmarkt.

2. For the sake of convenience they are referred to as 'companies' in this report. 
Leann Poeth and Peter Otten contacted the companies by telephone. In some cases, the alumnus was contacted to aid in finding the proper person within the company. The employer survey was conducted through the Internet by Flycatcher, a research bureau that specialises in data collections through Internet.

For maximising the response, the contact persons within the companies were first (through telephone) personally approached with the request to participate in the employer survey. After verbally agreeing to participate in the survey, the company was sent an email with information about the employer survey and an attachment containing general information about the FE\&BA. Before the summer holiday one reminder was sent. A second reminder was sent at the end of the summer holiday. In September, the companies who verbally agreed to participate but had not yet completed the employer survey were again contacted by telephone in a final attempt to increase the response rate.

These activities resulted in the participation of 52 companies $(69 \%$ response rate). Ten of the 75 companies explicitly declined participation in the employer survey due to company policy or because the questionnaire was in the English language.

After cleaning up the data, we were left with 48 partial or complete cases (64\% of the 75 companies). About a fifth of these 48 respondents answered less than $20 \%$ of the questions. On the other hand, about two thirds answered at least half, and half the respondents answered more than $80 \%$. Appendix 1 contains a list of the companies that participated in the employer survey.

It should be mentioned that this employer survey only covers large employers ( $>=$ 250 workers), while $25 \%$ of the 2002/2003 graduate cohort of the FE\&BA works in small and medium-sized enterprises $(<250$ workers). Hence, the survey is not representative as far as firm size is concerned. With respect to the representation by sector of industry, Table 1.1 shows that especially 'other commercial services firms' are underrepresented in the employer survey.

Table 1.1

Distribution of large employers (>= 250 workers) by sector of industry (\%)

\begin{tabular}{lll}
\hline & Graduate survey 2004 & Employer survey \\
\hline & & \\
Industrial companies & 21 & 30 \\
Banking/Insurance firms & 10 & 19 \\
Consultancy firms & 24 & 26 \\
Other commercial services firms & 29 & 14 \\
Other & 16 & 12 \\
\hline
\end{tabular}




\title{
2 Characterisation of the companies
}

\author{
International character of the branch of the company
}

Information on the branch of the company in which the respondent is involved is relevant because the company as such is not necessarily indicative for the work activities (for instance working for the technical department in a university). The results show that the vast majority $(75 \%)$ of the respondents are involved in the national branch of their company; 'only' $25 \%$ is involved in the international branch of their company. The remaining results in this report all refer to the branch (national or international) that the respondent is involved in.

Competition and competitive strategies of the company

In market economies companies differ in the degree of competition in the market in which they operate, and in the type of strategy they employ to compete in that market. To obtain a picture of the competitiveness of the market and the strategies companies use, we put forward five propositions:

- The company is active in a market with strong competition.

- The company competes mainly by keeping costs and prices as low as possible.

- The company competes mainly by recruiting and further developing highly talented employees.

- The company competes mainly by developing products or services that are different from those of its competitors.

- The company strives for as large as possible market share.

On a scale from 1 (not at all) to 5 (to a very high extent) the employers could indicate in how far the proposition concerned applies to their company. Figure 2.1 shows the percentage share of employers who indicate that the proposition concerned applies to a (very) high extent to their company (answer 4 or 5).

The majority of the companies strive for higher market shares in a highly competitive markets not so much by keeping costs and prices as low as possible, but rather by developing products or services that differ from those of its competitors and by recruiting and further developing highly talented employees (Figure 2.1). 
Figure 2.1

Percentage share of employers who indicate that the competition strategy applies to a (very) high extent to their company

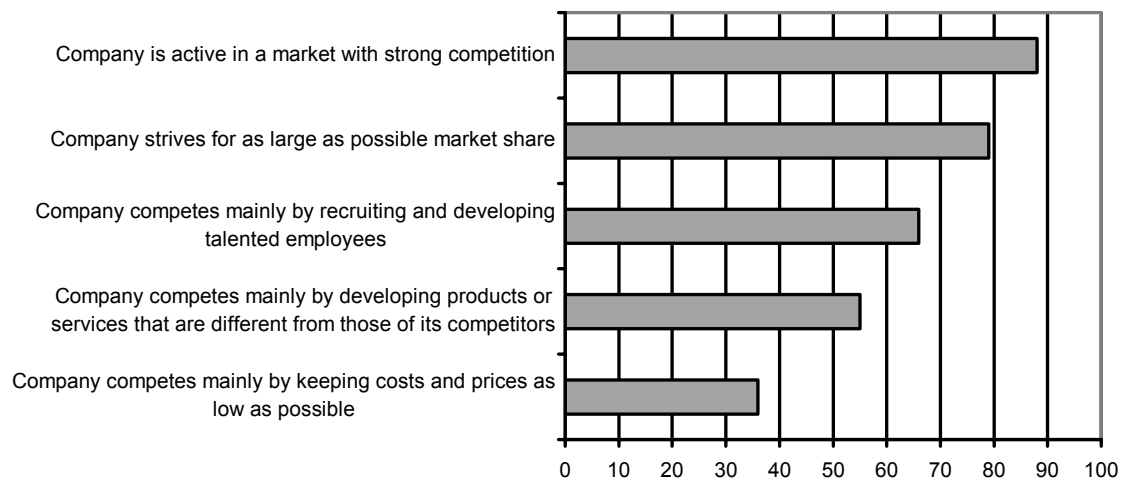

\section{Changes confronting companies}

The type of change that confronts a company is indicative for the kind of adaptability needed to respond to this change. The changes that confront companies can roughly cover four areas: technological change, organisational change, changes in the area of competition and markets, and changes in the products or services provided. For each of these kinds of changes the employers could indicate on a scale from 1 (not at all) to 5 (to a very high extent) in how far their company is subject to that particular kind of change.

Figure 2.2

Percentage share of employers who indicate that their company is to a (very) high extent subject to the type of change

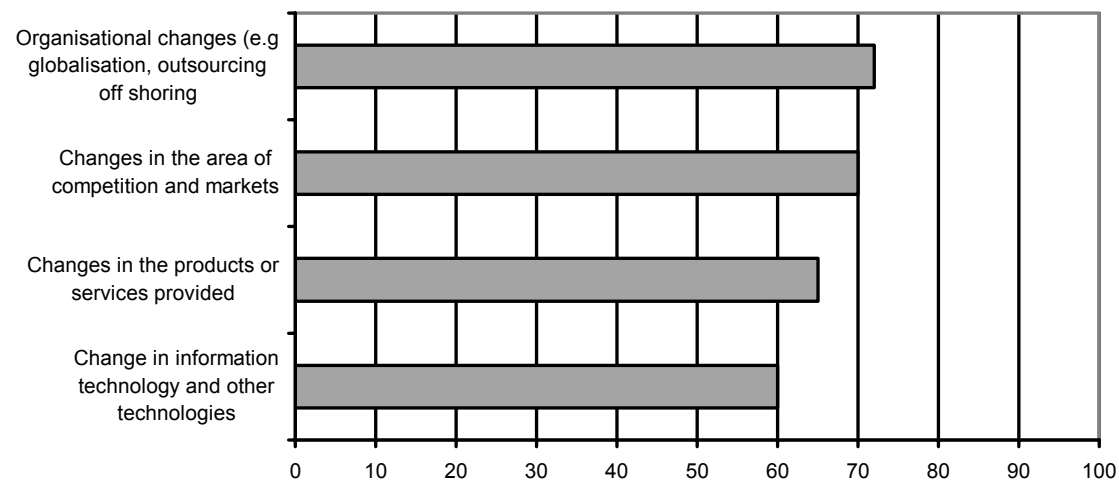


Figure 2.2 shows the percentage share of employers who indicate that their company is to a (very) high extent (answer 4 or 5 ) subject to that particular kind of change. As can be seen, on average the companies are subject to a moderately high degree of all four kinds of change. The companies are most often subject to organisational change and to changes in the area of competition and markets.

Respondents were asked to indicate other kinds of change to which their companies were exposed. Only about one in five respondents indicated that the company was subject to other changes. These changes included, among other things, changes in corporate climate (e.g. post-ENRON), changes in regulations/legislation, political influences and increasing regulatory requirements. 



\section{Recruitment- and HRD policy}

\section{Recruitment}

To gain insight into the extent and nature of the need for graduates of non-technical higher education study programmes in large companies, the employers were asked how many graduates of non-technical higher education study programmes their company recruits per year, and for what kinds of jobs these graduates are mainly recruited.

On average the surveyed companies recruit yearly approximately 54 graduates of non-technical study programmes at University level and approximately 36 graduates of non-technical study programmes at Higher Vocational Education (HBO) level. This implies that these companies together employ a total of to 1,900 graduates of nontechnical study programmes at University level and 930 graduates of non-technical study programmes at Higher Vocational Education level each year. The remaining results in this report all refer to recent graduates of university-level non-technical study programmes.

Figure 3.1

Jobs for graduates of university-level non-technical study programmes (\% of companies)

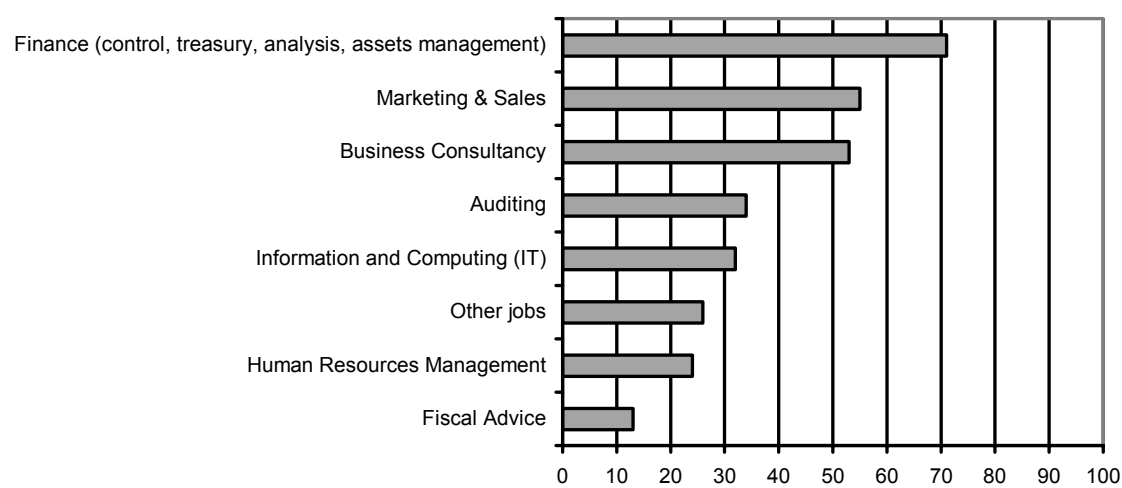

Multiple response question.

Figure 3.1 displays the kinds of jobs for which graduates of university-level nontechnical study programmes are mainly recruited. The results show that these graduates are mainly recruited for jobs in the sphere of finance, marketing \& sales and business consultancy. The category 'Other jobs' includes among other things (general) management, traineeships, logistics, competition law, and restructuring/corporate development. 
Immediate productivity

A high degree of immediate productivity of new personnel can be an important instrumental goal of a company. On average, new recruits are expected to start making a significant contribution to the company's productivity half a year (5.8 months) after starting work. This varies from 1 month to 18 months, and only a quarter of the companies are prepared to wait longer than six months before the recruit starts to contribute. The vast majority (89\%) of the companies takes specific measures to help new recruits to adjust to their new situation. This applies equally to companies that expect new recruits to start making a significant contribution soon after recruitment as to companies that are prepared to wait longer. In an open question the companies were asked to specify their measures to help new recruits to adjust. These measures can be categorised as follows in Figure 3.2:

Figure 3.2

Measures to help new recruits to adjust to their new situation (\%)

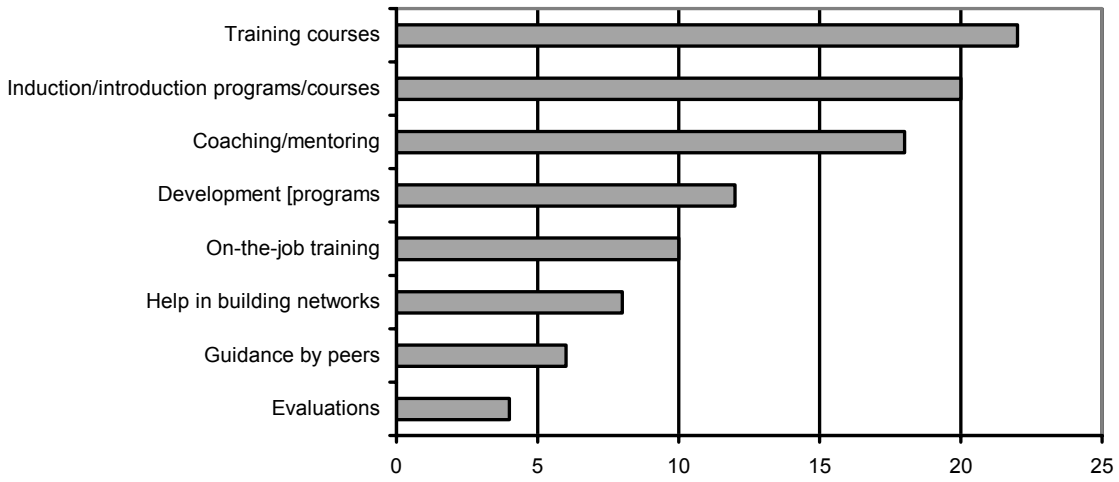

Human Resource Development

Almost all companies (94\%) also indicate that they take specific measures to stimulate the development of recruits in the first 5 to 10 years of their employment. These measures can be categorised into career development programs (43\%), training/study facilities (43\%) and coaching/mentoring (13\%).

\section{Turnover of personnel}

On average $17 \%$ of new recruits are likely to leave the firm within 5 years. This varies from $2 \%$ to $50 \%$, and only one out of seven companies expects more than $20 \%$ to leave in this period. To put this low level of expected turnover in perspective, we looked at data from the university graduates survey 2004. These data indicate that the turnover in large companies (>= 250 workers) is probably lower than the turnover in small and medium-sized enterprises (SME's): $22 \%$ of the economics graduates in SME's is looking for another job, and $40 \%$ has a temporary job. In large enterprises the figures are significantly lower: $16 \%$ is looking for another job and $33 \%$ has a 
temporary job. This suggests that larger enterprises more often pursue a strategy aimed at retaining a large proportion of recruits.

\section{Reasons for turnover}

The respondents were asked to indicate the extent to which turnover was related to strong internal selection or to spontaneous turnover. Over one third of the employers $(37 \%)$ indicate that the departure of new recruits in this period is to a (very) high degree a result of strong internal selection. In comparison, a little over a quarter of the employers $(27 \%)$ indicated that the departure of new recruits within their first 5 years is to a (very) high degree a result of spontaneous turnover. Several comments made by respondents suggest that internal selection and spontaneous turnover are not mutually exclusive. For example, one respondent remarked:

"We expect a very strong development of our recruits and we support and stimulate that. For some that is too fast and ambitious. So they leave".

In other words, internal selection consists largely in nurturing the best and brightest, and leaving those who can not reach the desired standard to draw their own conclusions. Remarks made by two other respondents further illustrate this point:

"People make their own choices but our HR policy is aimed at retaining the most talented recruits and we are successful in doing so".

"Even in times of reorganizations, extra effort is put in making sure the top recruits do not leave the company".

Several respondents expressed considerable faith in the quality of new recruits, due to strong initial selection:

"[The company] makes a significant investment in the recruitment process of top $Q$ candidates; it is unlikely that the candidate will underperform. A few years at [the company] definitely adds to the market value of a high-potential graduate; most graduates leave on own initiative".

"We have strong selection but already at recruiting level. Therefore it is rare that we have to reject recruits during their careers".

Some respondents pointed out that individual quality is often highly personal, and stressed that their personnel policy was strongly geared to benefit from this:

"[The company] has a very high retention rate related to the talent-driven recruitment policy (where a starting position is matched with the profile and preference of the candidate; not vacancy-driven where you look for the best candidate for a specific role)" 
"Talent Management strongly focuses to develop the person to the best of his/her potential. This also includes different career paths for different people within a large and diverse company."

"Progression is merit based. The culture at [the company] is that you are never in competition with colleagues. Part of reward is based on "contribution to the success of others". 


\title{
4 Selection criteria
}

\author{
Relevance of field of study
}

The employers were asked to indicate the relevance of the graduate's specific discipline or field of study when recruiting graduates of university-level non-technical study programmes. The answer to this question indicates the degree in which economics graduates are subject to competition from graduates of other study programmes. The answer also partially indicates the selection policy of the company regarding their need of non-technical university-level educated personnel.

When recruiting graduates of university-level non-technical study programmes, a small majority (58\%) of the employers indicates that the graduates' specific discipline or field of study is highly relevant (answer 4 or 5 on a scale from 1 'not at all relevant' to 5 'highly relevant').

Twenty employers elaborated on the relevance of the specific discipline or field of study: $36 \%$ of them elaborated that the specific discipline is only relevant for finance/ law jobs, and that competences $(27 \%)$, a broad field of interest $(9 \%)$, personality $(9 \%)$, academic level $(5 \%)$, study results $(5 \%)$ and experience $(5 \%)$ are more important than the specific discipline/ field of study. Finally $5 \%$ considers the specific discipline/ field of study merely as a confirmation of the graduate's interest/field of ambition.

\section{Relevance of selection criteria}

Some 10 criteria which may play a major role in the recruitment of new graduates were presented to the employers. They were asked to indicate for each of these 10 criteria whether or not they feel that this plays a major role in the recruitment of new graduates. The following 10 criteria were presented to the employers:

- Knowledge of own discipline

- $\quad$ Long-term development potential

- Versatility

- Innovative skills

- Management skills

- Interpersonal skills

- Intercultural communication skills

- $\quad$ Fit in the organisational culture

- Analytical skills

- Problem solving skills.

Figure 4.1 shows in how many companies these criteria play a major role in selecting new graduates. The selection criteria problem solving skills, interpersonal skills, analytical skills and long-term development potential appeared to be quite generally applied across all kinds of companies: over $90 \%$ of the companies indicate that these criteria play a major role in the selection of new graduates. In this respect it should be 
mentioned that the system of problem based learning in groups, which forms one of the main selling points of the UM, is expected to enhance the development of especially problem solving skills and interpersonal skills. By contrast, less than two thirds of the companies reported that management skills and knowledge of own discipline played a major role in the recruitment process.

Figure 4.1

Criteria that play a major role in the selection process when recruiting new graduates (\% of companies)

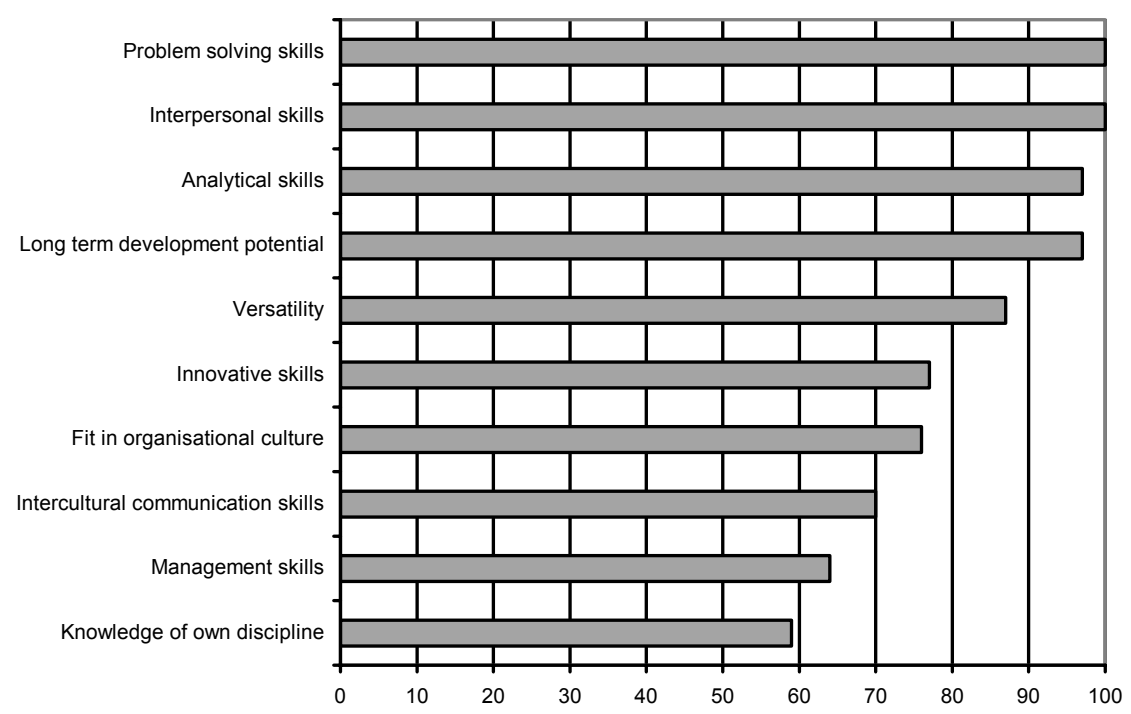

Multiple response question.

In addition the employers could name a maximum of 5 other criteria that play a major role in the selection process when new graduates are recruited. These other criteria could be classified into 6 categories, namely:

\section{- Entrepreneurship}

- Experience and skill development

- (Other) interpersonal skills

- (Other) intercultural or communication skills

- Other personal skills and qualities

- (Other) management skills.

For the classification of the other selection criteria into these 6 categories, see Appendix 3. Only the categories Entrepreneurship, Experience and skill development, and Other personal skills and qualities are relevant, since the other categories are already covered by the selection criteria from Figure 4.1 . 
Figure 4.2

Other criteria that play a major role in the selection process when recruiting new graduates (\%)

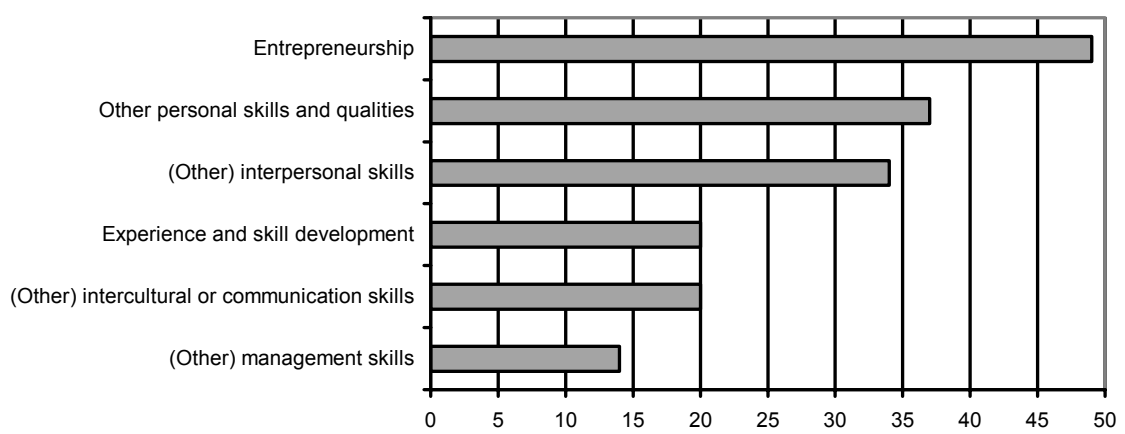

Figure 4.2 shows in how many companies these three criteria play a major role in selecting new graduates. Noticeable is that a large proportion of companies emphasized that skills and qualities that are related to the concept of 'entrepreneurship' were important criteria during the recruitment process.

Figures 4.1 and 4.2 give an impression of the proportion of companies which apply the different selection criteria. As such, this does not indicate the relative weight given to each criterion in the selection process. To assess this, employers were asked to fill in '10' for the criterion they considered most important in the selection process, ' 0 ' for the criterion they considered least important, and to assign the remaining criteria a score between 0 and 10 according to how important they considered them in comparison to these extremes. The average scores of the selection criteria are displayed in Figure 4.3.

Figure 4.3 paints a very different picture than Figures 4.1 and 4.2. Some criteria were regarded as important by a majority of companies, but were assigned a relatively low weight. Other criteria were assigned a high weight by the relatively few companies that regarded them as important. In order to gain a clearer view of this, Scheme 4.1 combines the two dimensions. 
Figure 4.3

Relative weight of the selection criteria (average score)

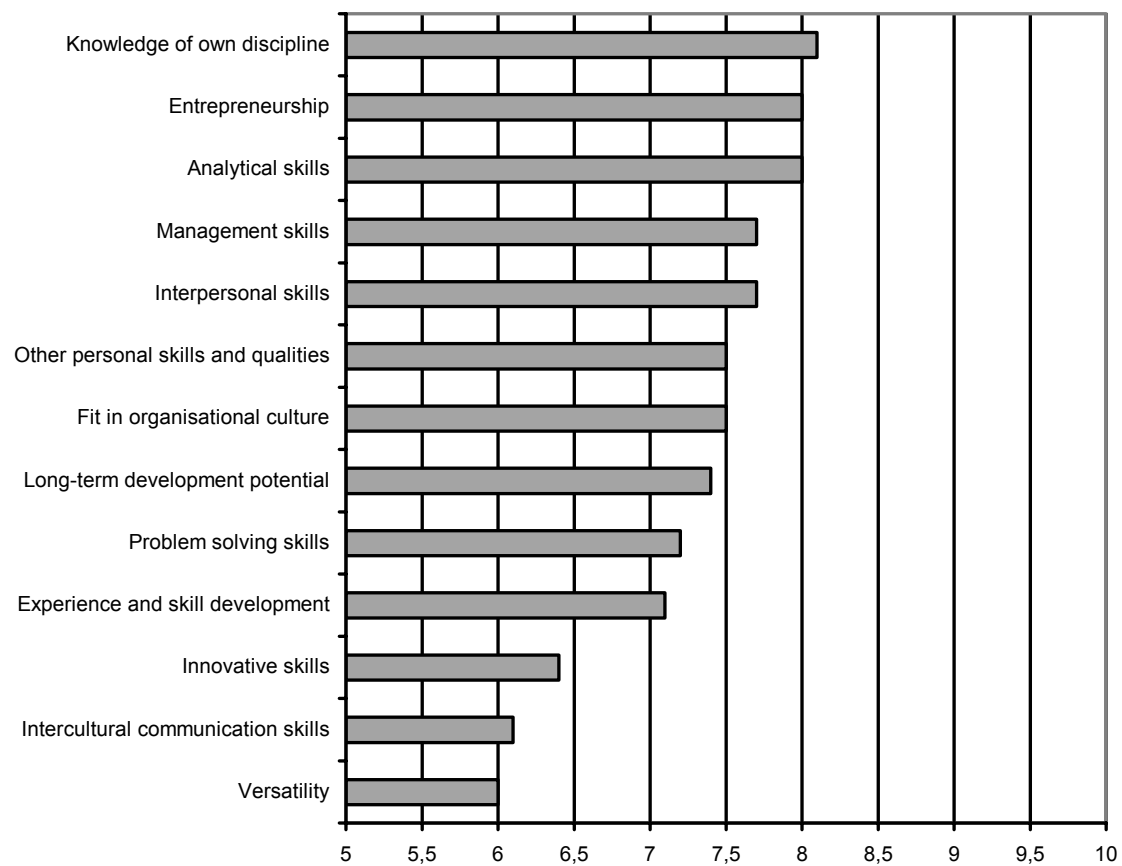

Scores ranging from 0 (least important) to 10 (most important)

Scheme 4.1

Classification of selection criteria

\begin{tabular}{|c|c|c|c|}
\hline \multirow{6}{*}{$\frac{\sum_{0}^{\infty}}{\frac{\Phi}{0}}$} & & \multicolumn{2}{|c|}{ Percentage of companies in which criterion plays a major role ${ }^{a}$} \\
\hline & \multirow{4}{*}{$\begin{array}{l}\text { above } \\
\text { average }\end{array}$} & above average & below average \\
\hline & & Interpersonal skills & Knowledge of own discipline \\
\hline & & Analytical skills & Entrepreneurship \\
\hline & & $\begin{array}{l}\text { Long-term development potential } \\
\text { Fit in organisational culture } \\
\text { Management skills }\end{array}$ & Other personal skills and qualities \\
\hline & $\begin{array}{l}\text { below } \\
\text { average }\end{array}$ & $\begin{array}{l}\text { Problem solving skills } \\
\text { Versatility } \\
\text { Innovative skills } \\
\text { Intercultural communication skills }\end{array}$ & Experience and skill development \\
\hline
\end{tabular}

Notes

a: $63 \%$ is the average percentage of companies in which the criteria played a major role

b: 7.21 is the average weight assigned by companies to the criteria

Interpersonal skills, analytical skills, long-term development potential, fit in organisational culture and management skills not only play more often than average a major role in the selection process but also weigh above average. The conclusion seems 
warranted that these are key selection criteria that are central to the process of recruiting non-technical graduates in a broad range of companies.

Problem solving skills, versatility, innovative skills and intercultural communication skills also play a major role more often than average in the selection process. However, they are given less than average weight by employers. These can be described as basic criteria that are often considered during recruitment, but that are not as decisive as certain other criteria.

Knowledge of own discipline, entrepreneurship, and other personal skills and qualities play less often than average a major role in the selection process, but when they do they are given more than average weight. This is indicative of distinctive recruitment strategies applied by different companies: most companies either find these criteria very important or not important at all.

Experience and skill development not only plays a major role less often than average in the selection process but is also assigned a lower than average weight. Although most companies assign a strong weight to the long term development potential of graduates, they do not appear to be very concerned that graduates lack some experience and skills at the time of recruitment.

\section{The graduates' opinion}

It would be interesting to differentiate more between different types of companies in terms of selection strategies applied. Unfortunately, the relatively small number of companies that participated in the employer survey means that further differentiation is difficult. To supplement the information provided in the employer survey we can turn to data from the annual nation-wide survey among new graduates of Dutch universities. ${ }^{3}$ Graduates were asked to indicate the level at which a number of competences are required in their present job. Some of these competences approximate the selection criteria that were assigned a strong weight in the selection process by companies. Table 4.2 shows the percentage share of economics graduates who indicated that the competences are required at a good/excellent level in their job, for the three most prevalent types of companies represented in the employer survey.

3. This graduate survey is known in the Netherlands as the WO-Monitor (WO is short for wetenschappelijk onderwijs or university education). 
Table 4.2

Required level of entrepreneurial competences of economics graduates, ${ }^{*} 2004$

(\% good/excellent level required)

$\begin{array}{rrr}\text { Industrial } & \text { Banking/ } & \text { Consultancy } \\ \text { companies } & \begin{array}{r}\text { Insurance } \\ \text { firms }\end{array} & \text { firms } \\ & & \end{array}$

\section{Knowledge of own discipline}

Knowledge of your own discipline

Ability to apply knowledge of the own discipline

Average

$\begin{array}{lll}82 & 74 & 79 \\ 82 & 85 & 82 \\ 82 & 80 & 81\end{array}$

Entrepreneurial competences:

- ability to notice problems and possibilities as they

arise

- ability to perform well under pressure

- ability to take decisive action

- ability to come up with new ideas and solutions

- willingness to stick your neck out

Average

$\begin{array}{lll}93 & 80 & 80 \\ 93 & 80 & 84 \\ 72 & 60 & 58 \\ 82 & 77 & 61 \\ 71 & 70 & 55 \\ 82 & 73 & 68 \\ & & \\ & & \\ 85 & 77 & 80 \\ 90 & 73 & 70 \\ & & \\ 85 & 77 & 72 \\ 87 & 76 & 74\end{array}$

Interpersonal competences:

- ability to work productively with others

- willingness to stand up for your own point of view

- willingness to take the point of view of others into account

Average

Analytical competences:

- ability to draw connections between different subjects

$85 \quad 77 \quad 87$

- ability to distinguish major priorities from secondary matters

- ability to construct or analyse logical arguments

Average

$93 \quad 85 \quad 90$

$90 \quad 85 \quad 92$

$89 \quad 82 \quad 90$

Long-term development potential:

- ability to learn new things

Management competences:

- ability to work within a budget, plan, or guideline

- ability to mobilise the capacities of others

- ability to perform tasks without supervision

$\begin{array}{lll}64 & 53 & 72 \\ 57 & 47 & 53 \\ 93 & 85 & 84 \\ 71 & 62 & 70\end{array}$

* Only graduates working in jobs requiring a university level of education in the own or a related field are included.

The graduate survey broadly underlines the emphasis employers lay on especially long-term development potential and analytical competences. As far as differences between types of companies are concerned, on balance there is little difference between the three types of companies in the extent to which competences relating to knowledge of own discipline are required. However, it is noticeable that in banking/insurance firms and in consultancy firms the ability to apply disciplinespecific knowledge seems even more important than the knowledge as such. Entrepreneurial competences are most often required at a high level in industrial 
companies, as are interpersonal competences and long-term development potential. Relatively few graduates working in consultancy firms report that entrepreneurial competences are important, while those working in banking/insurance firms are less likely to report high required levels of analytical and management competences than those working in the other types of firms. 



\section{Rating of university graduates}

\section{Rating of the competence levels of university graduates in general}

The employers were asked to rate in general the level of their job applicants with a recent university degree on the selection criteria. They could rate the competence levels on a scale from 1 (poor) to 5 (excellent). Figure 5.1 shows for each selection criterion the percentage share of employers who rate the level of recent university graduates in general as good or excellent (answer 4 or 5 ).

Employers rate the disciplinary knowledge, analytical skills and interpersonal skills of recent university graduates in general as good or excellent (over $70 \%$ of the employers rate the level as good/excellent). Employers are more reserved as far as the versatility, innovative skills, entrepreneurship and other personal skills and qualities of recent university graduates are concerned (less than $50 \%$ of the employers rate the level as good or excellent).

\section{Figure 5.1}

Rating of recent university graduates in general (\% good/excellent)

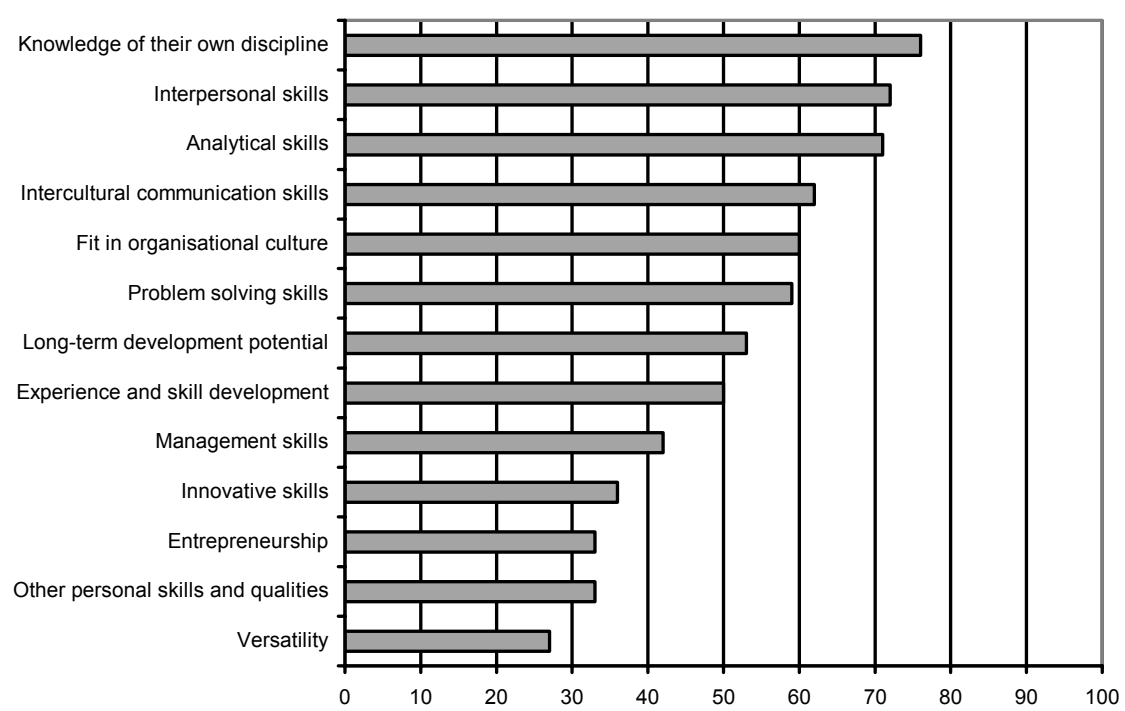

Answer 4 or 5 on a scale from 1 (poor) to 5 (excellent).

Rating of the competence levels of UM graduates

The employers were first asked whether or not they notice any differences between new UM graduates and new graduates from other universities in the recruitment process, and if so to compare the competence levels of new UM graduates with the 
competence levels of new graduates of other universities. Of the 30 employers who answered the first question, $40 \%$ indicated that they notice differences between new UM graduates and new graduates from other universities in the recruitment process. How these employers rate UM graduates is shown in table 5.1 in absolute numbers.

As far as employers noticing differences between UM graduates and graduates from other universities, they are very positive about graduates of the UM: on all selection criteria UM graduates score at least average or more often above average in the eyes of employers. Table 5.1 further shows that UM graduates in particular clearly score above average with respect to interpersonal skills and problem solving skills, and especially these criteria weigh heavily in the selection of recent university graduates (see Figure 4.3).

Table 5.1

The level of UM graduates, compared to the level of graduates from other universities $(\mathrm{N})$

\begin{tabular}{|c|c|c|c|}
\hline & $\begin{array}{l}\text { Level o } \\
\text { below average }\end{array}$ & $\begin{array}{l}\text { graduates } \\
\text { average }\end{array}$ & $\begin{array}{l}\text { s: } \\
\text { above average }\end{array}$ \\
\hline Interpersonal skills & 0 & 3 & 8 \\
\hline Problem solving skills & 0 & 3 & 8 \\
\hline Fit in organisational culture & 0 & 3 & 5 \\
\hline Versatility & 0 & 4 & 4 \\
\hline Intercultural communication skills & 0 & 4 & 4 \\
\hline Innovative skills & 1 & 4 & 4 \\
\hline Entrepreneurship & 0 & 3 & 4 \\
\hline Other personal skills and qualities & 0 & 2 & 4 \\
\hline Long-term development potential & 0 & 7 & 3 \\
\hline Analytical skills & 1 & 6 & 3 \\
\hline Management skills & 0 & 5 & 3 \\
\hline Knowledge of own discipline & 0 & 2 & 2 \\
\hline Total & 2 & 46 & 62 \\
\hline
\end{tabular}

Twelve employers' elaborated further on the performance of UM graduates. The 20 points they put forward are shown in Figure 5.2.

In addition, all employers were asked whether or not they are familiar with the problem-based learning (PBL) approach that is used at the UM, and if so whether or not the differences between UM graduates and graduates of other universities are related to the PBL approach used at the UM. Most employers (64\%) are familiar with the PBL approach that is used at the UM. Of the employers who are familiar with PBL, the majority (62\%) believes that differences between UM graduates and other graduates are related to PBL. Four employers elaborated further on this. All four indicated that UM graduates have the advantages of being well trained in how to work in (international) teams. As one employer put it: "Graduates well trained in how to work in teams; team politics; how to get results; different way of tackling problems". 
Figure 5.2

Employers' elaborations on UM graduates

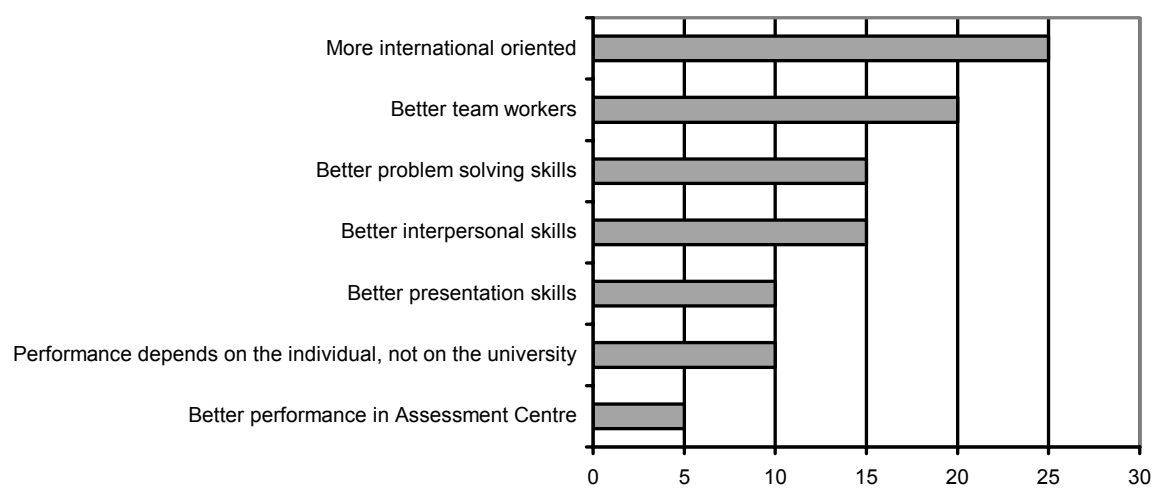

The graduates' opinion

In the annual nation-wide survey among new graduates of Dutch universities, the graduates were asked to indicate on a 5-point scale (from 1 'moderate level' to 5 'excellent level') both at which level a number of competences are required in their present job and at which level they have acquired these competences. Confrontation of the acquired level with the required level shows whether the acquired level is insufficient or sufficient for the required level. The results show that UM graduates more often indicate that their level of knowledge of the own discipline and the level of their ability to communicate in foreign languages, to interrelate different subjects, and to make one's meaning clear to others, as well as the level of their willingness to stand up for the own point of view is sufficient for their job than graduates from other universities. However, they indicate less often that their ability to learn new things is sufficient for the level that is required in their jobs than graduates from other universities. 



\section{Demand for closer ties with the Faculty of Economics and Business Administration}

Finally, the employers were asked whether or not they would like to have closer ties with the UM. The vast majority $(90 \%)$ of the respondents reacted in a positive way. Figure 6.1 shows that the employers most often want to obtain information about potential recruits or to give guest lectures.

Figure 6.1

Demand for closer ties with the UM (\%)

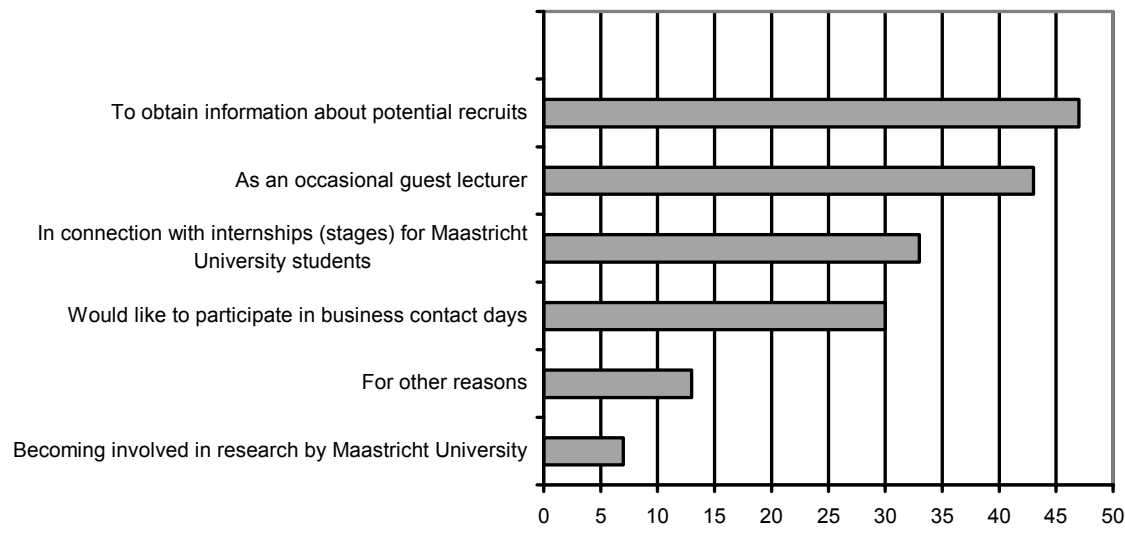

Multiple response question.

$\mathrm{N}=30$.

Six employers explicitly mentioned that they already maintain close ties with the UM. Three employers requested the UM to contact them, and 3 employers did not feel the need for closer ties. 



\section{Findings}

Most respondents are involved in the national branch of their company. Most companies are subject to changes in the areas of competition and markets, and to organisational change. Perhaps this is why most companies compete by developing products or services that differ from those of its competitors and by recruiting and further developing highly talented employees.

The surveyed national/international branches of companies recruit yearly in total approximately 1,900 graduates of non-technical study programmes at University level and approximately 930 graduates of non-technical study programmes at Higher Vocational Education level. The graduates of university-level non-technical study programmes are mainly recruited for jobs in the sphere of finance, marketing \& sales and business consultancy.

The new recruits are expected to start making a significant contribution to the company's productivity half a year after starting work. The vast majority of the companies takes specific measures to help new recruits to adjust to their new situation. These measures vary from induction programs and introduction courses to coaching, mentoring and on-the-job training. Almost all companies also indicate that they take specific measures to stimulate the development of recruits in the first 5 to 10 years of their employment. These measures include among other things regular assessment, personal/management development programs, regular training and learning events, mentoring and corporate universities.

On average $17 \%$ of new recruits are likely to leave the firm within 5 years. The departure of new recruits in this period is regarded by more employers as a result of strong internal selection (by $37 \%$ of the employers) than as a result of spontaneous turnover (by ( $27 \%$ of the employers).

In selecting new graduates, companies often take the graduate's interpersonal skills, analytical skills, long-term development potential, fit in organisational culture and management skills into account. They also put a lot of weight on these skills. The graduate's problem solving skills are also often taken into account. However, problem solving skills are given less than average weight in the selection process. Entrepreneurship less often than average plays a major role in the selection process, but when it does it is given more than average weight. On all of these selection criteria UM graduates score at least average or more often above average in the eyes of employers. UM graduates in particular clearly score above average with respect to interpersonal skills and problem solving skills. 
In this respect it should be mentioned that the majority of the employers $(64 \%)$ is familiar with the PBL approach that is used at the UM. Most of them believe that differences between Maastricht and other graduates are related to PBL. One employer characterised Maastricht graduates as follows: "much more sociable; better team players (real team players instead of 'people in a group'); consensus based; good problem solving skills".

Finally, almost all employers want to have closer ties with the UM, in particular for obtaining information about potential recruits or for giving guest lectures. 


\title{
Appendix 1: Companies that participated in the employer survey
}

\author{
ABN AMRO \\ ABP Investments \\ Accenture \\ Ahold \\ Akzo Nobel \\ Atos Origin \\ AUDI AG \\ AZL NV \\ Cargill \\ Delta Lloyd Groep \\ DPWN Business Consulting $\mathrm{GmbH}$ \\ DSM \\ Eiffel \\ ENECO Energie \\ Ernst \& Young \\ Fortis \\ Hase \\ Hay Group BV \\ Henkel KGaA \\ HSBC Trinkaus \& Burkhardt KGaA \\ ING Groep \\ KLM Royal Dutch Airlines \\ KPMG \\ KPN \\ L'Oréal \\ Marsh \\ Ministerie van Economische Zaken \\ Ministerie van Financiën \\ Nederlandse Mededingingsautoriteit \\ Océ NV \\ Ordina \\ Pricewaterhousecoopers \\ Procter \& Gamble \\ Rabobank \\ Roland Berger Strategy Consultants \\ Shell \\ Siemens \\ Solvay \\ The Boston Consulting Group \\ ThyssenKrupp \\ TNT \\ Twynstra Gudde \\ Unilever \\ Vodafone \\ 4 companies that wanted to remain anonymous
}





\title{
Appendix 2: Questionnaire employer survey
}

\author{
Employers Survey \\ Universiteit Maastricht \\ Faculty of Economics and Business Administration \\ (Interactive survey via internet or e-mail)
}

1. Are you involved in the national or international branch of <Company name>? national

international

The remaining questions refer to the branch (national or international) that you are involved in.

2. To what extent would you say the following statements apply to <company name>?

$$
\begin{array}{lcccc}
\text { not at all } & <----> & \text { to a very high extent } \\
1 & 2 & 3 & 4 & 5
\end{array}
$$

a. <Company name> strives for as large as possible market share.

b. <Company name> is active in a market with strong competition.

c. <Company name> competes mainly by developing products or services that are different from those of its competitors.

d. <Company name> competes mainly by recruiting and developing talented employees.

e. <Company name> competes mainly by keeping costs and prices as low as possible.

3. To what extent is <Company name> subject to the following kinds of change?

$$
\begin{array}{lcccc}
\text { not at all } & <----> & \text { to a very high extent } \\
1 & 2 & 3 & 4 & 5
\end{array}
$$

a. Change in information technology and other technologies.

b. Organisational changes (e.g. globalisation, outsourcing, off shoring).

c. Changes in the area of competition and markets.

d. Changes in the products or services provided.

4. Is <Company name> subject to other major types of change?

no

yes (please elaborate briefly): 
5. Roughly how many graduates of non-technical higher education study programmes are recruited by <company name> per year?

(e.g. economics, law, social/behavioural sciences, humanities)

approximately ..... graduates at University level

approximately ..... graduates at Higher Vocational Education level

Please note: The remaining questions in the questionnaire all refer to recent graduates of university-level non-technical study programmes

6. For what kinds of jobs do you mainly recruit these graduates?

Auditing

Information and Computing (IT)

Human Resources Management

Marketing \& Sales

Fiscal Advice

Business Consultancy

Finance (control, treasury, analysis, assets management)

Others:

7. When recruiting these graduates, how relevant is their specific discipline or field of study?

$$
\text { not at all relevant <----> highly relevant }
$$

$\begin{array}{lllll}1 & 2 & 3 & 4 & 5\end{array}$

Please elaborate briefly:

8. Approximately how long after starting work are new recruits expected to start making a significant contribution to <Company name's > productivity?

Approximately months

Please elaborate briefly:

9. Does <Company name $>$ take specific measures to help new recruits to adjust to their new situation?

no

yes

Please elaborate briefly:

10. Does <Company name> take specific measures to stimulate the development of recruits in the first 5 to 10 years of their employment?

no

yes

Please elaborate briefly: 
11. Can you give a rough estimate of the percentage of new recruits that are likely to leave the firm within 5 years?

Approximately $\%$

Please elaborate briefly:

12a. To what extent would you describe the departure of new recruits in this period as spontaneous turnover by <Company name $>$ ?

not at all <----> to a very high extent

$\begin{array}{lllll}1 & 2 & 3 & 4 & 5\end{array}$

Please elaborate briefly:

12b. To what extent is the departure of new recruits in this period a result of strong internal selection by <Company name>?

not at all <----> to a very high extent

$\begin{array}{lllll}1 & 2 & 3 & 4 & 5\end{array}$

Please elaborate briefly:

In the next few questions we would like to ask about the role that various criteria play in the recruitment of new graduates. Please indicate for each of these criteria whether or not you feel this plays a major role, and describe briefly why the criterion in question is important or not important as the case may be. We ask you to consider firstly the following criteria:

- Knowledge of their own discipline

- $\quad$ Long-term development potential

- Versatility

- Innovative skills

- Management skills

- Interpersonal skills

- Intercultural communication skills

- Fit in the organisational culture

- Analytical skills

- Problem solving skills

After answering these questions, we will ask you to indicate additional criteria that you feel are important in the recruitment process. 
13. When recruiting new graduates, would you say that the following graduates' criteria play a major role in the selection process?

$\begin{array}{lll} & \text { Yes } & \text { no } \\ \text { a. Knowledge of their own discipline } & 1 & 2 \\ \text { b. Long-term development potential } & 1 & 2 \\ \text { c. Versatility } & 1 & 2 \\ \text { d. Innovative skills } & 1 & 2 \\ \text { e. Management skills } & 1 & 2 \\ \text { f. Interpersonal skills } & 1 & 2 \\ \text { g. Intercultural communication skills } & 1 & 2 \\ \text { h. Fit in the organisational culture } & 1 & 2 \\ \text { i. Analytical skills } & 1 & 2 \\ \text { j. Problem solving skills } & 1 & 2\end{array}$

Please elaborate on your answers if you feel that this is necessary.

14. Name a maximum of 5 other criteria that play a major role in the selection process when new graduates are recruited:

k.

I.

m.

n.

o. 
15. Consider the following list of criteria as a whole. Assign each criterion a score according to the following procedure:

- Fill in '10' for the criterion you consider most important in the selection process.

- Fill in ' 0 ' for the criterion you consider least important in the selection process.

- Assign the remaining criteria a score between 0 and 10 according to how important you consider them in the selection process in comparison to these extremes.

$<N B$ : for criteria a to $j$, the yes answers given to question 13 will be displayed>

a. knowledge of their own discipline

score

b. long-term development potential

[ ]

c. versatility

d. innovative skills

e. management skills

f. interpersonal skills

[ ]

g. intercultural comm

[ ]

unication skills

[ ]

h. fit in organisational culture

[ ]

i. analytical skills

[ ]

j. problem solving skills

[ ]

k. <criterion a>

[ ]

I. $\langle$ criterion $b>$

[ ]

m. $<$ criterion $c>$

]

n. $\langle$ criterion $d>$

[]

o. <criterion e>

[ ]

[ ]

16. How would you rate your job applicants with recent university degree in general on these criteria?
a. knowledge of their own discipline
b. long-term development potential
c. versatility
d. innovative skills
e. management skills
f. interpersonal skills
g. intercultural communication skills
h. fit in organisational culture
i. analytical skills
j. problem solving skills
k. <criterion a>
I. $\langle$ criterion $b>$
m. $\langle$ criterion $c>$
n. <criterion $d>$
o. <criterion e>

poor <--------------> excellent

[1] [2] [3] [4] [5]

$\left[\begin{array}{llll}11 & {[2]} & {[3]} & {[4]}\end{array}\right]$

$[1]$ [2] [3] [4] [5]

$\left[\begin{array}{lllll}{[1]} & {[2]} & {[3]} & {[4]} & {[5]}\end{array}\right.$

$[1] \quad[2] \quad[3] \quad[4] \quad[5]$

$[1]$ [2] [3] [4] [5]

$[1] \quad[2] \quad[3] \quad[4] \quad[5]$

$[1] \quad[2] \quad[3] \quad[4] \quad[5]$

$[1] \quad[2] \quad[3] \quad[4] \quad[5]$

$[1]$ [2] [3] [4] [5]

$[1]$ [2] [3] [4] [5]

$[1]$ [2] [3] [4] [5]

$[1]$ [2] [3] [4] [5]

[1] [2] [3] [4] [5]

[1] [2] [3] [4] [5] 
17. In the recruitment process, have you noticed any differences between new Universiteit Maastricht graduates and new graduates from other universities? no -> go to question 19

yes

Please elaborate briefly:

18. How would you rate new Universiteit Maastricht graduates on the following criteria, compared to new graduates of other universities?

\begin{tabular}{|c|c|c|c|}
\hline & $\begin{array}{l}N \\
\text { age }\end{array}$ & $\begin{array}{l}\text { <-> above } \\
\quad \text { average }\end{array}$ & $10 \mathrm{r}$ \\
\hline$[-2]$ & {$[-1]$} & [0] [1] [2] & [9 \\
\hline$[-2]$ & {$[-1]$} & [0] [1] [2] & \\
\hline$[-2]$ & {$[-1]$} & [0] [1] [2] & \\
\hline$[-2]$ & {$[-1]$} & [0] [1] [2] & \\
\hline$[-2]$ & {$[-1]$} & [0] [1] [2] & \\
\hline$[-2]$ & {$[-1]$} & [0] [1] [2] & \\
\hline$[-2]$ & {$[-1]$} & [0] [1] [2] & \\
\hline$[-2]$ & {$[-1]$} & [0] [1] [2] & \\
\hline$[-2]$ & {$[-1]$} & [0] [1] [2] & \\
\hline$[-2]$ & {$[-1]$} & [0] [1] [2] & \\
\hline$[-2]$ & {$[-1]$} & [0] [1] [2] & \\
\hline$[-2]$ & {$[-1]$} & [0] [1] [2] & \\
\hline$[-2]$ & {$[-1]$} & [0] [1] [2] & \\
\hline$[-2]$ & {$[-1]$} & ] [1] [2] & \\
\hline$[-2]$ & {$[-1]$} & [1] [2] & \\
\hline
\end{tabular}

19. Are you familiar with the problem-based learning (PBL)approach that is used at Universiteit Maastricht?

no $->$ go to question 21

yes, slightly

yes, thoroughly

20. In your opinion, are the differences between Universiteit Maastricht graduates and graduates of other universities related to the problem-based learning approach used at Universiteit Maastricht?

no

yes

Please elaborate briefly: 
21. Would you like to have closer ties with Universiteit Maastricht?

no

yes, I am interested in training provided by Universiteit Maastricht

yes, I would like to participate in business contact days

yes, in connection with internships (stages) for Universiteit Maastricht students

yes, as an occasional guest lecturer

yes, to obtain information about potential recruits

yes, I am interested in becoming involved in research by Universiteit

Maastricht

yes, for other reasons

Please elaborate briefly:

22. Who completed the questionnaire?

Name(s) and job title(s):

\section{Adress:}

This is the end of the questionnaire.

Thank you kindly for your cooperation!

Click NEXT to send the questionnaire. 



\title{
Appendix 3: Classification of the other selection criteria
}

\author{
Entrepreneurship \\ Ambition \\ Effectiveness \\ Entrepreneurship \\ Initiative/guts \\ Knowledge of a specific market \\ Result driven \\ Stakeholder \\ Management \\ Commercial \\ Customer focus \\ Impact \\ Personal and organisational sensitivity \\ Personal drive \\ Quality conscious \\ Business acumen \\ Motivation \\ Winner mentality \\ Persuasiveness \\ Vision \\ Experience and skill development \\ Internships \\ Willing to take training (CFA) \\ Developing yourself and others \\ Experience in projects \\ Affinity wit B2B technical products and Services \\ Experience \\ Marks \\ IT skills/ affinity \\ Good University degree \\ (Other) interpersonal skills \\ Leadership skills \\ Team player \\ Cooperation \\ Team spirit \\ Team work
}

(Other) intercultural or communication skills

Willingness to work abroad

Internationality 
Command of English

Communication skills

Language Skills

Presentation skills

Other personal skills and qualities

Adaptability

Authenticity

Change capabilities

Creativity

Stress-proof

Structured thinking

Ability to work under pressure

Flexibility

(Human) interest

Enthusiasm

Flexibility/Mobility

Open for change

Respect for values

Strong personality

(Other) management skills

Have feeling for managerial

Management skills

Organizing and planning

Organizational skills

Practice management

Project planning 